\title{
KEABSAHAN PERKAWINAN SEDARAH MASYARAKAT ADAT BATAK TOBA MENURUT HUKUM ADAT
}

\author{
Aktor Primadona \\ (Mahasiswa Program S1 Fakultas Hukum Universitas Tarumanagara) \\ (E-mail: primadonaaktor@gmail.com)
}

Hj. Mulati, S.H., M.H.

(Corresponding Author)

(Dosen Fakultas Hukum Universitas Tarumanagara. Meraih Sarjana Hukum pada Fakultas Hukum

Universitas Tarumanagara, Magister Hukum pada Fakultas Hukum Universitas Tarumanagara)

\begin{abstract}
Marriage is a sacred activity because it relates to the religion and beliefs of each. The Batak Toba community is one of all tribes in Indonesia that adhere to their customs and customs, but lately there has emerged the phenomenon of blood marriages in the Batak Toba indigenous people because they feel like each other without thinking about the sanctions that will be received later. In this study, the issue was raised about how legitimacy of the blood marriage of the Batak Toba indigenous people according to customary law? The author examines the problem using normative methods. The results showed that the marriage of the Batak Toba community was not in accordance with the rules applicable in customary law, because the marriage system of the Batak Toba indigenous people themselves embraced an exogamous marriage system in which the Batak Toba indigenous people could marry the man or woman they liked must be outside the clan or the clan itself. Then in this study there are also ways to preserve the culture of the Batak Toba indigenous people who are increasingly disappearing because of the modern era that exists today.
\end{abstract}

Keywords: Batak Toba, Blood Marriages, Preserve the Culture of the Batak Toba 


\section{PENDAHULUAN}

\section{A. Latar Belakang}

Indonesia merupakan salah satu negara yang memiliki kekayaan, baik kekayaan alamnya serta kekayaan manusianya. Indonesia juga memiliki banyak aneka ragam suku, agama dan budaya. Indonesia yang merupakan negara kepulauan menyebabkan perbedaan kebudayaan yang mempengaruhi tingkah laku dan pola hidup masyarakat. Adat merupakan kebiasaan suatu masyarakat, dan kelompok-kelompok masyarakat yang lambat laun menjadikan adat itu sebagai yang seharusnya berlaku bagi semua anggota masyarakat dengan dilengkapi oleh sanksi sehingga menjadi hukum adat. ${ }^{1)}$

Dari berbagai macam suku yang ada, disini penulis akan mengulas lebih dalam tentang adat Batak, adat Batak sendiri aladah suku yang ada di Indonesia, sebagian besar tinggal di Sumatera Utara. Suku Batak terdiri beberapa sub suku yaitu: Batak Toba, Batak Karo, Batak Simalungun, Batak Mandailing, dan Batak Pakpak. Menurut sejarah di kalangan suku Batak, tempat perkampungan para leluhur suku bangsa Batak yang pertama berada di tepi danau Toba yang bertempat di Sianjur Mula-mula, di dataran kaki gunung Pusuk, kemudian para leluhur mulai berpencar ke beberapa daerah sekitarnya sehingga menimbulkan bahasa yang berbeda satu sama lain, disini penulis akan membahas tentang masyarakat adat Batak Toba.

Masyarakat adat Batak Toba sendiri dikelompokkan kedalam suatu Marga. Marga adalah satuan kerabat yang warganya banyak, dan seorang yang menjadi bagian dalam marga sudah berada 20 generasi keturunan atau lebih jauh dari kakek asal marga tersebut. ${ }^{2)}$

\footnotetext{
1) Tolib Setiady, Intisari Hukum Adat Indonesia dalam Kajian Kepustakaan, (Bandung: Alfabeta, 2008), hal. 1

2) J.C. Vergouwen, Masyarakat dan Hukum Adat Batak Toba, (Jakarta: Pustaka Azet, 1986), hal. XI
} 
Hubungan kekeluargaan masyarakat adat Batak Toba masih kuat dan terus dipelihara di mana pun mereka berada, agar dapat mengetahui hubungan kekeluargaan antara seseorang dengan yang lainnya, dilakukan dengan menelusuri silsilah leluhur beberapa keturunan di atas mereka yang dalam bahasa Batak disebut Martarombo atau Martutur. Martarombo atau Martutur adalah menentukan atau melihat titik pertalian darah yang terdekat dalam rangka menentukan hubungan kekeluargaan. ${ }^{3)}$

Hukum adat disebut sebagai hukum tidak tertulis yang hidup dalam masyarakat merupakan arti dari kepribadian bangsa Indonesia yang berakar dari kebudayaan bangsa. Setiap daerah tertentu terdapat suku dan memiliki hukum adat yang berbeda, akan tetapi perbedaan-perbedaan itu yang menjadi perekat persatuan bangsa Indonesia. ${ }^{4)}$

Di berbagai wilayah Indonesia sendiri masih banyak yang memegang teguh adat istiadat sendiri, contohnya masyarakat Lampung yaitu perkawinan antara anak perempuan dari clan yang bersistem patrilineal menantu laki-laki yang dijadikan anak angkat, agar menantu laki-laki yang dijadikan anak angkat laki-laki itu, dapat menerima warisan yang kelak diteruskan kepada cucunya. Lalu dari masyarakat Palembang terdapat perkawinan antara seorang wanita janda dengan saudara laki-laki almarhum dari suaminya. Bentuk perkawinan ini adalah sebagai akibat adanya maksud bahwa seorang istri telah dibeli oleh pihak suami dengan telah membayar uang jujur atau mahar.

Untuk mulai membicarakan perkawinan itu, maka patutah terebih dahulu mengenal tentang tiga macam sistem keturunan:
a. Masyarakat ke-Ibu-an (Matrilineal)
b. Masyarakat ke-Bapa-an (Patrinilial)

\footnotetext{
3) Richard Sinaga, Perkawinan Adat Dalihan Natolu, (Jakarta: Dian Utama, 2010), hal. 22

4) Bambang Danu Nugroho, Hukum Adat "Hak Menguasai Negara Atas Sumber Daya Alam Kehutanan \& Perindungan Terhadap Masyarakat Hukum Adat”, (Bandung: Refika Aditama, 2015), hal. 70
} 
c. Masyarakat ke-Ibu/Bapa-an (Bilateral atau Parental)

Ter Haar menyatakan bahwa perkawinan tersebut berarti urusan kerabat, keluarga, masyarakat, martabat, pribadi, dan serta menyangkut urusan keagamaaan, sebagaimana dikatakan Van Volenhoven jika dalam hukum adat sendiri banyak lembaga-lembaga hukum dan norma-norma hukum yang berhubungan dengan dunia di luar dan di atas kemampuan manusia. ${ }^{5)}$

Setiap manusia mempunyai hak untuk menyelenggarakan perkawinan sesuai dengan Undang-Undang Dasar Tahun 1945 atau disingkat UUD 1945, dalam Pasal 28B ayat (1) menyebutkan setiap orang mempunyai hak untuk membentuk keluarga dan mempunyai kesempatan untuk memiliki keturunan melalui perkawinan yang sah. ${ }^{6)}$ Menurut Pasal 1 Undang-Undang Nomor 1 Tahun 1974 tentang Perkawinan menjelaskan bahwa perkawinan adalah ikatan lahir dengan batin antara seorang pria dan seorang wanita sebagai seorang suami dan seorang istri dengan maksud membentuk rumah tangga yang bahagia dan kekal berdasarkan Ketuhanan Yang Maha Esa. ${ }^{7)}$

Perkawinan yang dalam arti hukum adat merupakan suatu ikatan antara seorang laki-laki dengan seorang perempuan untuk membina rumah tangga yang dilakukan secara adat istiadat dan agamanya masing-masing dengan melibatkan keluarga kedua belah pihak saudara maupun kerabat. Hukum perkawinan dalam arti adat adalah norma-norma hukum adat yang mengatur tentang bentuk perkawinan, tata cara pelamaran, pelaksanaan upacara perkawinan, dan putusnya suatu perkawinan di Indonesia. Norma-norma hukum adat perkawinan itu sendiri di berbagai daerah yang ada di wiayah Indonesia berbeda-beda, dikarenakan sifat kekerabatan, sifat adat istiadat, sifat agama dan sifat kepercayaan mereka yang berbeda-beda.

\footnotetext{
5) Hilman Hadikusuma, Hukum Perkawinan Adat, (Bandung: Mandar Maju, 1983), hal. 22

6) Pasal 28B ayat (1) Undang-undang Dasar Tahun 1945 (UUD 1945).

7) Pasal 1 Undang-undang Nomor 1 Tahun 1974 Tentang Perkawinan.
} 
Sahnya suatu perkawinan menurut hukum adat bagi masyarakat adat di Indonesia tergantung pada ajaran agama yang dianut masyarakat adat. ${ }^{8)}$ Dalam arti jika telah dilakukan menurut aturan hukum agamanya, maka perkawinan itu sudah sah menurut hukum adat, lain hanya bagi mereka yang belum menganut agama dan hanya menganut kepercayaan yang masih meyakini roh-roh dan dewa-dewa atau bisa disebut animisme ataupun dinamisme.

Di dalam bukunya, Prof. Hilman Hadikusuma menuliskan kekerabatan masyarakat hukum adat yang berdasarkan asymmetrisch connubium, melarang terjadinya antara seorang pria dengan seorang wanita yang memiliki marga yang sama. ${ }^{9)}$ Perkawinan harus dilakukan dengan melakukan perkawinan berulang searah dari satu bibit yang sama, pihak penerima (boru) dianjurkan dan dikehendaki untuk tetap mengambil dara dari pemberi dara (hula-hula).

Prof. Hilman Hadikusuma juga menerangkan bahwa larangan perkawinan sendiri telah ditentukan dalam Undang-undang No.1 Tahun 1974 Tentang Perkawinan. Tidak terdapat banyak larangan dengan hukum adat yang berlaku di Indonesia, namun masih terdapat hal-hal yang berlainan karena pengaruh struktur masyarakat adat yang bersifat unilateral menurut garis patrilineal maupun matrilineal.

Dalam masyarakat adat Batak Toba yang sifat keturunannya bersifat patrilineal dan bersendi pada dalihan na tolu (tungku tiga) terdapat larangan perkawinan semarga, yang dimana pria dan wanita dari satu keterunan (marga) yang sama dilarang melakukan perkawinan. ${ }^{10)}$ Karena sistem perkawinan adat Batak Toba menganut sistem perkawinan eksogami (perkawinan di luar kelompok), sehingga menjadikan masyarakat Batak Toba sangat melarang keras

\footnotetext{
8) Pasal 2 Undang-undang Nomor 1 Tahun 1974 Tentang Perkawinan.

9) Hilman Hadikusuma, Hukum Perkawinan Adat dengan Adat Istiadat dan Upacara Adatntya, (Bandung: Citra Aditya Bakti, 2003), hal. 100

10) Hilman Hadikusuma, Hukum Perkawinan Indonesia menurut Perundangan Hukum Adat Hukum Agama. (Bandung: Mandar Maju 2007) hal. 59
} 
adanya perkawinan semarga karena perkawinan semarga namariboto dianggap sebagai perkawinan sedarah/inces.

Perkawinan sedarah itu sendiri adalah perkawinan yang dilakukan berdasarkan satu keluarga yang sama atau bisa diartikan dengan satu marga yang sama, lalu ada permasalahan perkawinan kerena adanya janji dari leluhur yang tidak membenarkan bila marga satu dengan marga lainnya melakukan perkawinan, karena permasalahan dalam masyarakat Batak Toba adalah mereka tidak bisa melakukan perkawinan karena terbentur aturan adat isitadat yang berlaku.

Berdasarkan uraian diatas, penulis ingin membahas keberlakuan hukum adat yang ada saat ini, lalu bagaimana pelaksanaannya serta cara penyelesaian masalah tersebut, maka dalam penulisan ini penulis tertarik untuk mengangkat judul "KEABSAHAN PERKAWINAN SEDARAH MASYARAKAT BATAK TOBA MENURUT HUKUM ADAT"

\section{B. Permasalahan}

Berdasarkan latar belakang di atas, maka perumusan masalah dalam penelitian ini adalah:

1. Bagaimana keabsahan perkawinan sedarah masyarakat Batak Toba menurut hukum adat?

2. Bagaimana pelaksanaan perkawinan adat di masyarakat adat Batak Toba?

\section{Metode Penelitian}

Metode merupakan suatu unsur yang harus ada dalam suatu penetilitan yang berfungsi untuk mengembangkan ilmu pengetahuaan. ${ }^{11)}$ Untuk memperluaskan ilmu pengetahuan khususnya di bidang hukum perkawinan diperlukan suatu penulisan penelitian hukum. Penulisan penelitian hukum merupakan suatu kegiatan ilmiah yang didasarkan pada suatu metode, sistematika dan pemikiran

\footnotetext{
${ }^{11)}$ Soerjono Soekanto, Pengantar Penelitian Hukum (Jakarta: UI Press, 1981), hal. 7
} 
tertentu yang bertujuan untuk mempelajari satu atau beberapa gejala hukum tertentu dengan menganalisanya. Untuk mengetahui masalah-masalah dan agar penulis bisa melakukan suatu evaluasi permasalahan yang telah disebutkan sebelumnya, sehingga dalam pengumpulan suatu bahan-bahan, fakta-fakta, dan data yang diperlukan penulis menggunakan metode yaitu sebagai berikut:

1. Jenis Penelitian

Ada dua jenis penelitian hukum, yang pertama penelitian hukum normatif dan yang kedua penelitian hukum empiris (sosiologis). Penulisan tersebut sesuai dengan apa yang dikemukakan oleh Prof. Soerjono Soekanto, bahwa: Penelitian hukum itu berdasarkan tujuannya terdiri atas pertama; penelitian hukum normatif, yang mencakup penelitian mengenai asas-asas hukum, penelitian mengenai sistematika hukum, penelitian mengenai taraf sinkronisasi hukum, mengenai penelitian sejarah hukum, dan mengenai penelitian perbandingan hukum. Kedua; mengenai penelitian hukum sosiologis atau empiris, yang mencakup mengenai penelitian terhadap identifikasi hukum (tidak tertulis) dan mengenai penelitian terhadap efektivitas hukum. ${ }^{12}$

Jenis penelitian yang penulis gunakan untuk penulisan ini adalah jenis penelitian hukum normatif. Penelitian hukum normatif adalah penelitian hukum yang meletakkan hukum sebagai salah satu bangunan sistem norma. ${ }^{13)}$ Sistem norma yang dimaksud adalah mengenai asas-asas, norma, kaidah dari peraturan perundangan, putusan pengadilan, perjanjian serta doktrin atau ajaran.

2. Sifat Penelitian

Penelitian hukum normatif adalah penelitian hukum yang meletakkan hukum sebagai sebuah bangunan sistem norma. Sistem norma yang dimaksud

\footnotetext{
12) Ibid., hal. 51

13) Mukti Fajar ND dan Yulianto Achmad, Dualisme Penelitian Humum Normatif dan Empiris, Cetakan Ke-1, (Yogyakarta: Pustaka Belajar, 2010), hal. 34.
} 
adalah mengenai asas-asas, norma, kaidah dari peraturan perundangan, putusan pengadilan, perjanjian serta doktrin. ${ }^{14)}$

Disini peneliti mengunakan sifat penelitian deskriptif, yaitu bahwa peneliti dalam menganalisis berkeinginan untuk memberikan suatu gambaran atau pemaparan atas subjek dan objek penelitian sebagaimana hasil penelitian yang dilakukan penulis ${ }^{15)}$

3. Jenis dan Sumber Data

Dalam suatu penelitian selalu diperlukan bahan atau data yang akan dicari untuk diolah dan selanjutnya dianalisis untuk mencari jawaban dari permasalahan penelitian yang diajukan. ${ }^{16}$ ) Dalam penelitian ini selalu diperlukan bahan atau data yang akan dicari yang nantinya diolah dan selanjutnya dianalisis untuk mencari jawaban dari permasalahan penelitian yang diajukan.

a. Bahan Hukum Primer, terdiri atas peraturan perundangan-undangan, yurisprudensi atau keputusan pengadilan (lebih-lebih bagi penelitian yang berupa studi kasus) dan perjanjian internasional (traktat). Bahan hukum primer yang digunakan dalam penulisan ini penulis menggunakan Undang-Undang Dasar Negara Republik Indonesia Tahun 1945, Undang-Undang Nomor 1 Tahun 1974 tentang Perkawinan dan Peraturan Pemerintah Nomor 9 Tahun 1975 Tentang Perkawinan.

b. Bahan Hukum Sekunder, yaitu bahan hukum yang dapat memberikan penjelasan terhadap bahan hukum primer, yang dapat berupa rancangan perundang-undangan, hasil penelitian, buku-buku teks,

\footnotetext{
14) Ibid.,

15) Ibid., hal. 183

16) Ibid., hal. 41
} 
jurnal ilmiah, surat kabar (koran), pamphlet, brosur, dan berita internet.

c. Bahan Hukum Tersier, yaitu bahan yang memberikan petunjuk maupun penjelasan terhadap bahan hukum primer dan bahan hukum sekunder, contohnya seperti kamus hukum, ensiklopedia, indeks kumulatif.

4. Teknik Pengumpulan Data

Dalam pengumpulan data untuk kepentingan skripsi ilmiah ini, penulis menggunakan cara pengumpulan data dengan studi pustaka terhadap data premier, bahan hukum sekunder dan bahan non-hukum, serta dengan melakukan wawancara. Penelusuran bahan-bahan hukum tersebut dapat dilakukan dengan membaca, melihat, mendengarkan, maupun melalui media internet.

5. Teknik Analisis Data

Analisis data dalam penelitian ini menggunakan analisis kualitatif, artinya menguraikan data yang diolah secara rinci kedalam bentuk kalimat-kalimat (deskriptif). Sifat analisis deskriptif maksudnya adalah, bahwa peneliti dalam menganalisis berkeinginan untuk memberikan gambaran atau pemaparan atas subjek dan objek penelitian yang di lakukannya. Disini peneliti tidak melakukan justifikasi terhadap hasil penelitiannya tersebut. ${ }^{17)}$

Menurut Pasal 1 angka 2 Undang-Undang Nomor 12 Tahun 2011 tentang Pembentukan Peraturan Perundang-undangan, Peraturan Perundang-undangan adalah peraturan tertulis yang memuat norma hukum yang mengikat secara umum dan dibentuk atau ditetapkan oleh lembaga negara atau pejabat yang berwenang melalui prosedur yang ditetapkan dalam peraturan perundang-

\footnotetext{
17) Ibid., hal. 183
} 
undangan. Maka, pendekatan perundang-undangan (statude approach) adalah pendekatan dengan menggunakan legislasi dan regulasi.

\section{PEMBAHASAN}

\section{A. Analisis Keabsahan Perkawinan Sedarah Masyarakat Adat Batak Toba} Menurut Hukum Adat.

Perkawinan memang tidak bisa dipisahkan dalam kehidupan manusia, cepat atau lambat manusia akan melakukan suatu peristiwa hukum berupa perkawinan, namun perkawinan itu sendiri pun didasari oleh berbagai macam, ada yang melakukan perkawinkan karena memang sudah waktunya, lalu ada perkawinan yang dilakukan guna untuk mengikatkan tali kekerabatan dan ada juga perkawinan yang dilakukan karena kecelakaan sebelum perkawinan atau yang biasa disebut hamil di luar nikah.

Perkawinan juga didasari oleh perasaan suka sama suka dan ada juga yang didasari oleh keadaan terpaksa, keadaan terpaksa inilah yang membuat umur perkawinan itu sendiri menjadi lebih cepat karena adanya tekanan dari para pihak untuk melakukan perkawinan, dan perkawinan yang di idam-idamkan oleh seluruh manusia adalah atas dasar suka sama suka, namun suka sama suka ini juga terdapat halangan karena terbentur dengan peraturan yang mengatur tantang pelaksanaan perkawinan itu, hal ini yang menjadikan manusia untuk mengesampingkan peraturan tersebut agar terlaksananya prosesi perkawinan yang di idam-idamkan, namun mereka tidak memikirkan dampak atau sanksi jika mereka melalukan perkawinan tersebut. Larangan perkawinan bukan hanya terdapat dalam peraturan perundang-undangan saja yang mengatur tentang larangan perkawinan, namun ada peraturan dari hukum agama dan hukum adat. Peraturan tersebut dibuat berdasarkan apa yang seharusnya terjadi pada perkawinan ini agar terciptanya perkawinan yang tidak melanggar aturan yang berlaku. 
Dalam penulisan skripsi ini penulis ingin menjelaskan masalah perkawinan sedarah yang ada di masyarakat adat Batak Toba. Masyarakat adat Batak Toba sendiri terkenal dengan patuhnya masyarakat tersebut kepada hukum adat, maka masyarakat adat Batak Toba masih melestarikan dan memelihara budaya tersebut bahkan diwariskan kepada keturunan mereka supaya adat atau budaya tersebut tidak hilang walaupun sudah memasuki zaman modern saat ini, namun pada saat ini masyarakat Batak Toba itu sudah ada yang tidak memelihara dan melestarikan budaya Batak itu karena melihat budaya Batak sudah ketinggalan zaman atau sudah tidak sesuai dengan zaman modern. Pada hakekatnya, perkawinan pada masyarakat adat Batak Toba sepenuhnya bersifat patrilineal. Tujuannya untuk melestarikan keturunan di dalam garis lelaki. Menurut peraturan hukum keluarga, ia terus terbilang ke dalam kelompok kerabat.

Masyarakat Batak Toba ada yang mengilangkan marga di belakang nama karena berbagai alasan tertentu, dan ada yang lebih memilih budaya sekarang daripada budaya adat Batak Toba karena dianggap terlalu rumit dan memakan waktu yang lama, tentang tidak diberlakukannya budaya tersebut, masyarakat Batak Toba ada yang ingin melaksanakan suatu perkawinan namun terbentur karena larangan adatnya dilarang kawin, dan masyarakat adat Batak Toba beranggapan untuk mengeyampingkan hukum adat itu agar apa yang diingikan itu tercapai. Contoh halnya adalah perkawinan, Masyarakat Batak Toba melakukan perkawinan sedarah atau semarga yang sudah seharusnya dilarang namun karena perasaan suka sama suka maka aturan tersebut di kesampingkan oleh kedua belah pihak. Hambatan alami untuk benar-benar mematahkan belenggu sistem eksogami adalah rasa takut akan marahnya murka roh dan para leluhur. Rasa ketakut itu lebih meningkat oleh beberapa pasangan terhadap larangan perkawinan tersebut, yang akan berakhir buruk bagi para pelakunya perkawinan sedarah tersebut.

Masyarakat Batak Toba sendiri menganut bentuk perkawinan eksogami atau perkawinan diluar clan mereka, yang berarti masyarakat adat Batak Toba menikah 
dengan pemuda atau pemudi yang diuar dari keluarga atau clan mereka, namun siapa sangka bahwa jika perkawinan yang didasari oleh perasaaan saling suka, kebanyakan mereka tidak menghiraukan pantangan atau larangan jika melakukan perkawinan dalam satu clan atau keluarga tersebut. Masyarakat adat Batak Toba jika ingin melakukan perkawinan yang dianggap dilarang oleh adat mereka akan beralih melakukan perkawinan menurut aturan nasional saja, jadi perkawinan mereka sah tercatat di akta nikah catatatan sipil namun tidak melakukan prosesi adat istiadat.

Di dalam perkawinan sendiri dapat ditemukan istilah perkawinan sedarah, perkawinan sedarah sendiri adalah perkawinan yang dilakukan suami dan istri yang dalam sejatinya terikat dalam satu keluarga yang dekat, dalam beberapa kasus perkawinan sedarah masyarakat Batak Toba

Melihat hasil wawancara dengan pemandu anjungan suku Batak Toba di TMII, beliau menjelaskan bahwa bukan hanya masyarakat Batak Toba saja yang melarang adanya perkawinan sedarah atau semarga, perkawinan sedarah atau semarga tersebut dilakukan karena adanya pergeseran prilaku masyarakat adat Batak Toba sendiri, jikalau tetap melakukan perkawinan sedarah mereka yang melakukan akan dikeluarkan dari daerah tersebut dan mereka percaya jika melakukan perkawinan sedarah atau semarga tersebut akan mendapatkan kesialan yang menimpa pasangan tersebut, menurut tanggapan beliau memang sekarang sedikit banyaknya ada yang melakukan perkawinan semarga jadi mereka mengeyampingkan adat istiadat tersebut, dan sanksi yang di dapatkan oleh pasangan tersebut sudah tidak terlalu parah karena sudah adanya peraturan hak asasi manusia yang melindungi setiap warga negara Indonesia dari kesewenangwenagan penguasa.

Melihat hasil wawancara dengan bapak Hanafi S.H., M.H. dikatakan Melihat struktur kekerabatan adat Batak, masyarakat Batak mengambil garis keturunan dari laki-laki atau patrilineal, sehingga untuk mempertahankan sistem kekerabatan 
itu mereka menggunakan sistem perkawinan eksogami jujur, eksogami merupakan sistem perkawinan dari luar clan, karena mereka menganggap bahwa orang yang lahir dari marga yang sama adalah orang yang lahir dari perut yang sama atau dongan sabutuha dan itu satu prinsip yang dipegang sampai hari ini, sehingga ketika orang Batak yang menikah dalam marga yang sama dia dianggap telah melakukan perkawinan sedarah atau incest, dan itu dilarang sekalipun dalam fakta fisiknya mereka tidak sedarah atau memiliki ikatan darah yang dekat, karena sedarah itu dikonotasikan sebegai semarga tanpa melihat seberapa jauh dan dekatnya hubungan kekerabatannya.

Beliau mengatakan bahwa masyarakat Batak menikah dalam marga yang sama mereka akan mendapat sanksi seperti di eks komunikasikan artinya di usir atau dianggap bukan lagi bagian dari masyarakat adat Batak sementara tertulis didalam Undang-undang Perkawinan untuk salah satu syarat sahnya perkawinan yaitu tidak adanya hubungan darah yang dekat, tidak di jelaskan semarga atau tidak, Undang-undang Perkawinan hanya menjelaskan menurut adat agama dan kepercayaannya bukan menurut adat istiadat.

Jika melihat dalam masyarakat itu terdapat perubahan lalu mereka mengacu pada peraturan perkawinan bahwa yang semarga itu bukan hubungan darah yang dekat ya boleh boleh saja jika itu dilakukan dalam perkawinan nasional karena dalam Undang-undang Perkawinan tersebut tidak jelas mengatur tantang semarga karena hubungan sedarah itu diartikan dalah hubungan darah yang dekat. Persoalannya tergantung pada mereka yang mau menggunakan tentang perkawinan nasional atau mempertahankan aturan dari kakek moyangnya, jika melihat keabsahan perkawinan sedarah menurut hukum adat itu sudah pasti salah, namun jika melihat dari perkawinan nasional itu sah sah saja.

Bentuk perkawinan yang paling biasa adalah yang didahului dengan pertunangan, hal ini terjadi karena kemauan orang tua maupun oleh pilihan bebas pihak muda-mudi. Pertunangan disusul oleh pembahasan tentang jumlah emas 
kawin, yang diberikan pada waktu sebelum pernikahan dilangsungkan. Selain itu, ada pula bentuk perkawinan lain yang tidak begitu sering terjadi tentang perkawinan lari, pemuda dibantu beberapa kawannya, mencuri perempuan idamannya dengan kekerasan, baik karena si gadis tidak mengkehendakinya, atau karena si perempuan tidak diserahkan kepadanya secepat yang di inginkannya. Si laki-laki tersebut membawanya ke rumahnya, atau ke tempat lain yang cocok dan memuaskan segala keinginannya. Perlakuan kekerasan ini memberi hak kepada parboru atau pihak perempuan untuk meminta emas kawin yang lebih besar sebagai ganjaran, dan belakangan ini ada ada pula kecenderungan Gubernemen untuk menjatuhkan hukuman.

Di samping perkawinan lari, ada pula perkawinan setelah terjadi perkosaan. Hal ini sering dijadikan untuk memperlakukan si gadis yang di dambakan untuk mengiyakan perkawinan. Tetapi, terlampau sering tindak perkosaan dilakukan karena perasaan nafsu yang menggebu-gebu.

Perkawinan lari atas persetujuan bersama isitilah ini berarti perempuan pergi mengendap-endap untuk meninggalkan lingkungan orang tua bersama laki-laki yang ia mau. Hal ini biasanya merupakan reaksi terhadap tuntunan keluarga yang terlalu memaksakan untuk mengawinkan si perempuan dengan laki-laki yang tidak disenangi, atau mengenai hilangnya pembahasan mengenai jumlah uang emas karena parboru atau pihak perempuan menuntut lebih.

Perkawinan disertai godaan gadis, brntuk perkawinan ini artinya adalah mengharuskam diri kepada laki-laki yang dikehendakinya, dan memberikan diri dengan maksud mengharuskan untuk kawin, atau mengharuskan orangtuanya untuk melaksanakan perkawinan.

Selain itu ada Perkawinan disertai mengabdi, maksudnya adalah si laki-laki tinggal di rumah pihak perempuan, dikarenakan saudaranya terlalu miskin untuk melunasi emas kawin, atau karena gadis anak pertama, dan orang tua tidak mau 
berpisah dengan dia. Perkawinan disertai pengabdian di rumah pihak perempuan juga sepenuhnya berwatak patrilineal.

Perkawinan levirate atau ganti tikar dan perkawinan janda dalam bentuk ini, janda tidak kembali kepada kerabatnya sendiri, melainkan kawin dengan kerabat dekat suami yang meninggal, dengan kerabat jauh, atau dengan orang asing, dalam kasus pertama, emas kawin tidak diminta, dalam kedua yang terakhir ada, dan parboru atau pihak perempuan pun kembali tampil ke panggung

Selain itu terdapat perkawinan saudara perempuan yang dimana laki-laki duda kawin dengan saudara perempuan istrinya yang telah meninggal ini sering terjadi jika istri pertama meninggal tanpa dikarunai seorang anak.

Terakhir ada perkawinan Bigami dan poligami perkawinan ini berarti orang melalui kedua jalan ini oleh berbagai alasan, yang paling sering karena si isteri pertama tidak membuahkan anak.

Di lingkungan masyarakat Batak Toba pelaksanaan perkawinan yang berlaku adalah adat naso gok yaitu pemberlakuan perkawinan antara pria dan wanita tanpa melalui proses peminangan dikarenakan sudah terjadi mangalua, dimana si wanita sudah berada ditangan kerabat pria, dan adat na gok, yaitu pemberlakuan perkawinan dengan acara peminangan yang dilakukan oleh orang tua dari kerabat pria di sertai upacara atau pasu-pasu yang di adakan di gereja.

Tata cara adat na gok biasanya dimulai dari kedatangan pihak pria yang tidak resmi ke tempat wanita dalam rangka perjajakan. Jika pintu terbuka untuk mengadakan acara peminangan maka pihak orang tua akan memberikan tanda mau atau yang disebut tanda holong dan pihak wanita memberi tanda mata, jenis barang-barang pemberian itu berupa kain atau cincin emas. Pertukaran tanda ini kemudian dianjutkan dengan marhori-hori dinding atau marhusip, yaitu pembicaraan antara pihak yang melanggar dan dilamar terbatas dalam hubungan kerabat terdekat dan belum di ketahui umum. 
Beberapa waktu kemudian barulah dengan resmi kedatangan pihak kerabat pria kepada kerabat wanita untuk melakukan marhata sinamot yang artinya membicarakan uang jujur, dan disusul pula dengan pelaksanaan pulung saut yaitu pria yang mengantarkan wadah sumpit berisi lauk dan pauknya, yang diterima oleh pihak wanita yang lalu mengadakan jambar kepada para anggota kerabat secara beruntut, mulai dari anggota kerabat marga ibu hula-hula, anggota marga ayah dongan tubu, anggota marga menantu boru dan orang-orang tua pengetuai.

Dengan selesainya acara tersebut barulah dibicarakan waktu perkawinan, kemudian diberitahukan pada gereja dalam rangka pelaksanaan pasu-pasu. Pihak gereja mengeluarkan pengumumannya yang pertama tinting $I$ apabila dengan tinting pertama ini tidak ada para pihak yang mengajukan keberatan, maka dilanjutkan dengan tinting II. Sementara itu orang tua kedua calon mempelai melakukan martupol yang artinya adalah melaksanakan kesaksian dan menanda tangani persetujuan atas perkawinan anak-anak mereka. Setelah itu barulah masuk ke acara tinting III yang disebut manjalo pasu-pasu, yaitu penentuan acara upacara gereja terhadap anugerah Tuhan. Dalam acara gereja ini baik pria maupun wanita tidak lagi berpakaian adat, jika perlu mempelai hanya menggunakan selendang atau ulos.

Sesudah upacara gereja selesai, dimana perkawinan keduannya telah sah, maka keduanya telas sah, maka ke dua mempelai dibawa ketempat wanita, yang diterima oleh para anggota kerabat dan para undangan. Pada saat mana semua tandok adat atau beras sumpit yang dibawa pihak wanita atau boru di serah terimakan. Kedua mempelai duduk bersanding didampingi oleh orang tua mereka, dan menerima ucapan selamat serta barang barang hadiah perkawinan dari para hadirin, antara lain ulos hela, kain adat dari pihak boru dan ulos boru dari mempelelai pria.

Didalam upacara ini diadakan makan bersama dengan para hadirin, dan setelah selesai makan bersama dan penerimaan hadiah perkawinan dari para 
hadirin, maka upacara selesai dan hadirin boleh ke tempat masing-masing. Tetapi kerabat kedua mempelai masih tetap tinggal untuk melaksanakan mabbagi jabbar dijabu yaitu pembagian barang-barang hadiah para angota kerabat secara berurut, mula-mula untuk bonaniari atau nenek dari mempelai wanita, sulang-sulang, lalu untuk kerabat pria, baru untuk saudara-saudara pria dari ayah mempelai wanita yang dilanjutkan dengan saudara-saudara wanita dari ayah mempelai wanita yang disebut dengan para paramai yang artinya penggendong dimasa kecil. Selanjutnya semua pembagian untuk anggota dekat baru dilanjutkan untuk kerabat lain-lain dan para pemuka kampung.

Semua hadiah-hadiah itu adalah tanggungan dari kerabat pria. Sebaliknya jika ada pula marbagi jambar di jambar dialaman ialah pemberian hadiah dari pihak mempelai pria yang kesemuanya disebut ulos baik ulos dalam arti sebenarnya dan dalam maupun dalam bentuk uang. Selesai pembagian jambar barulah dilakukan mangihut di ampang yaitu mempelai wanita diantarkan ketempat mempelai pria yang dibarengi dengan rombongan kerabat pria dengan memberikan bakul tertutup ulos berisikan bahan makanan yang di junjung oleh para namarbaju kerabat pria. Di tempat kedatangan pria mempelai disambut dan diterima oleh kerabat pria lainnya dan diadakan acara makan bersama dengan para undangan yang disebut daulat ni sipanganon.

Jika perkawinan itu dilakukan kediaman pria, maka pihak wanitalah yang dbolehkan pulang lingkungan orang tuanya, untuk kemudian dibawa lagi oleh para tantenya ketempat pria. Begitu pula setelah upacara resmi perkawinan mempelai pria akan melakukan paulak une yaitu berkunjung ketempat mertuanya untuk mengatakan terimakasih atas berjalannya upacara acara perkawinan dengan baik. Dalam kunjungan ini pihak pria membawa wadah brisikan makanan. Kemudian beberapa waktu setelah itu pihak wanita melakukan maningkir tangga, yaitu berkunjung ke tempat pria untuk melihat keadaan mempelai wanita. Dalam kunjungan ini disertai rombongan namarnaju pihak wanita yang secara bergurau 
akan menanyakan pengalaman mempelai wanita. Kunjungan ini merupakan kunjungan adat, terakhir dalam rangka upacara perkawinan, dimana juga pihak wanita membawa lauk pauk makanan dengan wadah yang dibawa mempelai pria ketika datang melakukan paulak une. Jika pria yang kawin itu bukan anak bungsu yang artinya siappudan, maka setelah perkawinan ia akan manjae yaitu memisah tempat kediaman untuk berdiri sendiri dan berumah tangga sendiri, berpisah dari orang tua.

Perkawinan adalah salah satu perbuatan yang sakral atau suci karena berhubungan dalam bentuk ibadah dari agama atau kepercayaan masing-masing manusia, serta menjadi kewajiban bagi setiap manusia agar terciptanya suatu peristiwa hukum dimana perkawinan sendiri di catatkan dalam suatu ikatan yang sah dan mengikat antara kedua belah pihak. Perkawinan juga menjadi hal yang penting karena perkawinan sendiri memiliki aturan-aturan atau larangan-larangan bagaimana setiap perkawinan tersebut dapat dilaksanakan tanpa adanya suatu hambatan. Dari berbagai larangan perkawian tersebut salah satu larangan perkawinan yang sering mendapat sorotan adalah perkawinan sedarah.

Dalam masyarakat Batak Toba sedarah itu merupakan satu marga karena mereka mengangap bahwa mereka lahir dari darah yang sama tidak memandang jauh atau dekatnya hubungan darah tersebut. Itulah yang menjadi hambatan masyarakat adat Batak Toba lalu sedikit banyaknya mereka banyak melakukan perkawinan sedarah tersebut melalui perkawinan nasional atau hanya sah menurut hukum tanpa adanya kata sah dari para pemuka adat setempat, karena dalam Undang-undang No 1 Tahun 1974 Tentang Perkawinan Pasal 2 ayat 1 yang berbunyi perkawinan adalah sah, apabila dilakukan menurut hukum masingmasing agamanya dan kepercayaan itu. Jadi disini tidak ada tertulis menurut adat istiadat yang berlaku, sedangkan dalam Undang-undang Dasar 1945 Pasal 18b ayat 2 yang berbunyi Negara mengakui dan menghormati kesatuan-kesatuan masyarakat hukum adat beserta hak-hak tradisionalnya sepanjang masih hidup dan 
sesuai dengan perkembangan masyarakat dan prinsip Negara Kesatuan Republik Indonesia, yang diatur dalam undang-undang.

Disini penulis melihat adanya ketidaksesuaian antara apa yang dituliskan dalam Undang-Undang Dasar 1945 dengan apa terjadi dalam pelaksanaanya sehari-hari, karena setiap masyarakat Batak Toba yang ingin melakukan perkawinan sedarah mereka menempuh perkawinan tersebut melalui hukum nasional, yang dimana dalam hukum adat perkawinan sedarah atau semarga tersebut dilarang, namun dalam kenyataannya negara tidak mempersalahkan adanya suatu perkawinan tersebut.

Perkawinan adalah salah satu perbuatan yang sakral dan suci karena berhubungan dalam bentuk ibadah dari agama atau kepercayaan masing-masing manusia, serta menjadi kewajiban bagi setiap manusia agar terciptanya suatu peristiwa hukum dimana perkawinan sendiri di catatkan dalam suatu ikatan yang sah dan mengikat antara kedua belah pihak. Perkawinan juga menjadi hal yang penting karena perkawinan sendiri memiliki aturan-aturan atau larangan-larangan bagaimana setiap perkawinan tersebut dapat dilaksanakan tanpa adanya suatu hambatan. Dari berbagai larangan perkawian tersebut salah satu larangan perkawinan yang sering mendapat sorotan adalah perkawinan sedarah.

Masyarakat adat batak beranggapan bahwa jika orang bermarga sama berarti orang tersebut adalah semarga, karena sifat keturunannya yang mengambil keturunan dari laki-laki (patrilineal) beranggapan jika mereka mempunyai bapak moyang yang sama, dengan demikian hal tersebut yang menjadi dasar masyarakat adat Batak Toba memegang teguh adat istiadatnya.

Dalam sistem perkawinan masyarakat Batak Toba sendiri menganut sistem perkawinan eksogami yaitu perkawinan diluar clan atau diluar dari marga mereka, itu yang mengakibatkan sistem kekerabatan mereka yang menganggap bahwa jika melakukan perkawinan sedarah atau semarga akan mendapat musibah atau kesialan yang terjadi pada pasangan tersebut jika melakukan perkawinan sedarah 
tersebut. Memang masyarakat Batak Toba dianggap yang paling taat dan patuh kepada adat atau aturan aturan para leluhur karena mereka dibekali oleh orang tua mereka agar menjaga dan melestarikan budaya Batak Toba itu agar tidak hilang di telan zaman. Namun berjalannya waktu kini budaya Batak Toba seakan terkikis oleh zaman karena pengaruh zaman modern. Mereka seakan mengangap bahwa budaya Batak itu sendiri sudah kolot dan tidak perlu di lestarikan lagi.

Masyarakat adat Batak Toba juga sudah banyak yang merantau dan menetap di luar kampung halamannya, guna untuk memperbaiki ekomoni mereka, seiring berjalannya waktu masyarakat Batak Toba sendiri seakan acuh terhadap warisan nenek moyang karena sudah berbaur dengan budaya lain dimana mereka merantau saat ini. Mereka mengangap bahwa budaya Batak Toba itu sendiri sudah ketinggalan zaman, karena budaya mereka yang sedemikian rumit dan membutuhkan waktu yang sangat lama, ketika masyarakat adat Batak Toba melakukan perwakinan menggunakan proses perkawinan adat mereka akan mengikuti prosesi adat istiadat yang berupa manor-tor atau biasa disebut dengan menari, lalu juga ada ucapan berbalas kata kata dari pihak kerabat isteri dan pihak suami lalu ada prosesi pemberian ulos atau selendang dari pihak keluarga. Itulah yang membuat masyarakat Batak seakan merasa bahwa adat Batak Toba ini terasa ketinggalan zaman serta rumit karena harus mengikuti rangkaian acara yang sedemikian rupa.

Oleh karena itu tidak sedikit dari masyarakat Batak Toba yang melakukan perkawinan hanya melakukan acara pemberkatan atau akad lalu dilanjutkan dengan resepsi keluarga dekat saja, karena mengingat efisien waktu dan pengeluaran, karena jika menggunakan adat akan memakan pengeluaran yang tidak sedikit. Masyarakat adat Batak Toba melakukan perkawinan secara nasional atau tidak melalui adat bukan hanya karena keterbatasan waktu dan biaya, manun juga karena terbentur dengan larangan perkawinan oleh adat istiadat sendiri. Beberapa orang melakukan perkawinan melalui perkawinan nasional karena 
mereka menganggap mereka akan terbebas dari larangan adat istiadat itu sendiri. Masalah yang biasa dihadapi oleh masyarakat adat Batak adalah mereka melakukan perkawinan sedarah atau semarga jadi mereka beranggapan bahwa jika perkawinan dilakukan melalui perkawinan nasional maka masalah itu akan terselesaikan

Akibat melakukan perkawinan semarga jika dilihat dari Undang-undang Nomor 1 Tahun 1974 Tentang Perkawinan memang tidak disebutkan bahwa perkawinan semarga tersebut dilarang, dalam Undang-undang hanya menyebutkan yang dilarang tersebut adalah perkawinan sedarah. Jika melihat dari hasil wawancara dengan para narasumber atau orang yang dianggap mengerti tentang permasalahan ini, masing-masing dari mereka mengatakan bahwa perkawinan sedarah pada masyarakat adat Batak Toba itu dilarang karena dalam masyarakat adat Batak Toba sedarah itu merupakan semarga karena mereka mengangap bahwa mereka lahir dari darah yang sama tidak memandang jauh atau dekatnya hubungan darah tersebut.

Hal tersebut yang menjadi hambatan masyarakat adat Batak Toba lalu mereka banyak melakukan perkawinan sedarah tersebut melalui perkawinan nasional atau hanya sah menurut hukum tanpa adanya kata sah dari para pemuka adat setempat, karena dalam Undang-undang No 1 Tahun 1974 Tentang Perkawinan Pasal 2 ayat 1 yang berbunyi perkawinan adalah sah, apabila dilakukan menurut hukum masing-masing agamanya dan kepercayaan itu. Jadi disini tidak ada tertulis menurut adat istiadat yang berlaku, sedangkan dalam Undang-undang Dasar 1945 Pasal $18 \mathrm{~b}$ ayat 2 yang berbunyi Negara mengakui dan menghormati kesatuankesatuan masyarakat hukum adat beserta hak-hak tradisionalnya sepanjang masih hidup dan sesuai dengan perkembangan masyarakat dan prinsip Negara Kesatuan Republik Indonesia, yang diatur dalam undang-undang.

Disini penulis melihat adanya ketidaksesuaian antara apa yang dituliskan dalam Undang-undang Dasar 1945 dengan apa terjadi dalam kehidupan sehari- 
hari, karena setiap masyarakat Batak yang ingin melakukan perkawinan sedarah mereka menempuh perkawinan tersebut melalui hukum nasional, yang dimana dalam hukum adat perkawinan sedarah atau semarga tersebut dilarang, namun dalam kenyataannya negara tidak mempersalahkan adanya suatu perkawinan tersebut.

Akibat perkawinan sedarah menurut pernyataan dari beberapa narasumber bahwa perkawinan sedarah dalam masyarakat Batak Toba tersebut dilarang karena mereka menganggap bahwa mereka yang semarga tersebut adalah sedarah tanpa melihat dekat atau jauhnya hubungan kekerabatan tersebut. Jika penulis kaitkan wawancara dengan teori yang dituliskan diatas bahwa benar jika perkawinan sedarah masyarakat adat Batak Toba itu sendiri dan dilarang oleh hukum adat karena sistem perkawinan mereka yang menganut sistem perkawinan eksogami atau kawin diluar klan mereka

Melihat dari proses perkawinan masyarakat adat Batak Toba sendiri terlihat bahwa ada kerumitan atau memakan waktu yang lama, karena masyarakat adat Batak Toba beranggapan bahwa setiap acara adat istiadat harus disaksikan dan dihadiri oleh kerabat pihak suami atau isteri karena sifatnya yang sakral dan untuk membangun silaturahmi antara pihak suami atau isteri. Masyarakat adat Batak Toba juga banyak yang bengapan bahwa proses perkawinan adat Batak Toba terkesan membosankan dan memakan waktu yang lama, maka tidak heran dari sedikit banyaknya masyarakat adat Batak melakukan perkawinan bukan secara adat namun melakukan perkawinan resepsi biasa.

\section{B. Analisis pelaksanaan perkawinan adat di masyarakat adat Batak Toba.}

Upaya melestarikan budaya Batak sendiri tidak hanya dilakukan ketika melakukan acara adat saja, namun juga memberikan pembelajaran sejak dini, karena untuk mengenalkan adat itu sendiri memakan waktu yang lama, karena zaman sekarang masyarakat adat batak yang tidak mencantumkan marganya 
kedalam nama si anak, inilah yang sangat di sayangkan karena berawal dari hal yang kecil saja bisa akan berdampak besar kedepannya. Bukan hanya memberikan pembelajaran dini manun juga ikut serta dalam acara-acara kegiatan adat istiadat di daerah itu, karena saat ini tidak hanya di daerah Sumatera Utara saja yang terdapat acara adat istiadat namun di kota-kota lain pun terdapat acara adat guna untuk membangun kekeluargaan itu sendiri dengan masyarakat adat Batak lainnya.

Melihat pelaksanaan perkawinan masyarakat Batak Toba yang membutuhkan waktu serta susunan acara yang banyak, disitu masyarakat adat Batak Toba merasa bahwa perkawinan ini yang sudah ketinggalan zaman dan mereka seakan meninggalkan tradisi dan adat istiadat dari para leluhur, menurut para narasumber yang diwawancara masarakat sendiri yang harus peka atau peduli terhadap warisan nenek moyang mereka karena ituah yang menjadikan negara ini menjadi beraneka ragam karena banyaknya budaya yang ada di Indonesia ini. Karena negara pun mengakui dan menghormati segala kesatuan-kesatuan hukum adat beserta hak-hak tradisinalnya selama masih sesuai dengan perkembangan masyarakat dan prinsip Negara Kesatuan Republik Indonesia

\section{PENUTUP}

\section{A. Kesimpulan}

Berdasarkan analisis diatas penulis berkaitan dengan penelitian yang dilakukan dan berdasarkan dari keseluruhan bab-bab yang telah dijelaskan di atas, maka dapat ditarik kesimpulan bahwa:

1. Perkawinan sedarah yang dilakukan masyarakat adat Batak Toba tersebut tidaklah sah, karena tidak sesuai dengan ketentuan dan aturan yang telah ada dan diatur dalam hukum masyarakat adat Batak Toba itu sendiri, karena masyarakat adat Batak Toba mengangap bahwa sedarah merupakan semarga terlepas dari jauh dan dekatnya garis kekeluargaannya 
2. Perkawinan sedarah itu sendiri juga dilarang dalam Undang-Undang Perkawinan karena masih adanya ikatan darah yang terdapat pada pada Pasal 8 huruf a yang berbunyi berhubungan darah dalam garis keturunan kebawah atau ke atas.

3. Tidak adanya korelasi yang jelas menurut Pasal 2 Undang - Undang Nomor 1 Tentang Perkawinan dengan Pasal 18b Undang - Undang Dasar 1945. Karena didalam Pasal 18 huruf b Undang - Undang Dasar 1945 disebutkan bahwa Negara mengakui dan menghormati kesatuan-kesatuan masyarakat hukum adat beserta hak-hak tradisionalnya sepanjang masih hidup dan sesuai dengan perkembangan masyarakat dan prinsip Negara Kesatuan Republik Indonesia, yang diatur dalam undang-undang, namun dalam Pasal 2 UndangUndang Perkawinan Nomor 1 Tahun 1974 Tentang Perkawinan disitu di sebutkan bahwa perkawinan adalah sah, apabila dilakukan menurut hukum masing-masing agamanya dan kepercayaan itu. Disini tidak adanya kejelasan bagaimana aturan hukum adat berlaku bagi Undang - Undang Perkawinan sedangkan negara seharusnya mengakui dan menghormati kesatuan-kesatuan hukum adat yang berlaku.

4. Serta upaya pelestarian adat Batak Toba itu sendiri masih sangat kurang karena melihat dari masyarakat Batak Toba itu sendiri seolah-olah masyarakat mengangap bahwa istiadat tersebut sudah tidak relevan lagi jika dilakukan di zaman sekarang

\section{B. Saran}

Saran yang dapat diberikan oleh penuis mengenai topik yang penulis angkat adalah:

1. Pemerintah dan perguruan tinggi kiranya dapat mengadakan suatu kegiatan penyuluhan terhadap pemberlakuan hukum adat itu sendiri, agar tidak terjadi ketidakpahaman dalam masyarakat serta guna mengetahui sejauh mana hukum adat itu berlaku di masyarakat. 
2. Pemerintah juga harus lebih melihat keadaan yang terjadi di dalam masyarakat guna untuk menerapkan aturan yang ada karena setiap aturan yang ada pasti harus mengikuti aturan yang utama grundnorm

3. Masyarakat harus lebih bijak dalam menentukan perkawinan karena sudah tertulis dengan jelas bagaimana larangan-larangan perkawinan yang tidak diperbolehkan Undang - Undang maupun hukum adat itu sendiri sehingga tidak menimbulkan suatu tindak pelanggaran hukum

4. Upaya pelestarian budaya Batak Toba itu sendiri harus di dasari dari diri masyarakat itu sendiri, serta harus lebih merasa bahwa adat istiadat tersebut bukanlah hal yang ketinggalan zaman namun adalah warisan yang diberikan nenek moyang kita dahulu yang seharusnya wajib kita lestarikan

\section{DAFTAR PUSTAKA}

\section{A. Buku}

Hadikusuma, Hilman, Hukum Perkawinan Adat, Bandung: Mandar Maju, 1983. , Hukum Perkawinan Adat dengan Adat Istiadat dan

Upacara Adatntya, Bandung: Citra Aditya Bakti, 2003. , Hukum Perkawinan Indonesia menurut Perundangan

Hukum Adat Hukum Agama. Bandung: Mandar Maju 2007.

ND, Mukti Fajar dan Yulianto Achmad, Dualisme Penelitian Humum Normatif dan Empiris, Cetakan Ke-1, Yogyakarta: Pustaka Belajar, 2010.

Nugroho, Bambang Danu, Hukum Adat "Hak Menguasai Negara Atas Sumber

Daya Alam Kehutanan \& Perindungan Terhadap Masyarakat Hukum Adat", Bandung: Refika Aditama, 2015.

Setiady, Tolib, Intisari Hukum Adat Indonesia dalam Kajian Kepustakaan, Bandung: Alfabeta, 2008.

Sinaga, Richard, Perkawinan Adat Dalihan Natolu, Jakarta: Dian Utama, 2010. Soekanto, Soerjono, Pengantar Penelitian Hukum Jakarta: UI Press, 1981. 
Vergouwen, J.C., Masyarakat dan Hukum Adat BatakToba, Jakarta: Pustaka Azet, 1986. 